\title{
Contrasting extracellular enzyme activities of particle-associated bacteria from distinct provinces of the North Atlantic Ocean
}

\author{
Carol Arnosti $^{1}$ *, Bernhard M. Fuchs ${ }^{2}$, Rudolf Amann $^{2}$ and Uta Passow ${ }^{3 \dagger}$ \\ 1 Department of Marine Sciences, University of North Carolina at Chapel Hill, Chapel Hill, NC, USA \\ ${ }^{2}$ Department of Molecular Ecology, Max Planck Institute for Marine Microbiology, Bremen, Germany \\ ${ }^{3}$ Alfred Wegener Institute for Polar and Marine Research, Bremerhaven, Germany
}

\section{Edited by:}

Diana R. Nemergut, University of

Colorado at Boulder, USA

\section{Reviewed by:}

David C. Smith, University of Rhode Island, USA

Steven Allison, University of California at Irvine, USA

\section{*Correspondence:}

Carol Arnosti, Department of Marine Sciences, University of North Carolina at Chapel Hill, CB \#3300, 3117A Venable Hall, Chapel Hill, NC 27599-3300, USA.

e-mail: arnosti@email.unc.edu

tPresent address:

Uta Passow, Marine Sciences

Institute, University of California at Santa Barbara, Santa Barbara, CA, USA.
Microbial communities play a key role in the marine carbon cycle, processing much of phytoplankton-derived organic matter. The composition of these communities varies by depth, season, and location in the ocean; the functional consequences of these compositional variations for the carbon cycle are only beginning to be explored. We measured the abilities of microbial communities in the large-particle fraction (retained by a $10-\mu \mathrm{m}$ pore-size cartridge filter) to enzymatically hydrolyze high molecular weight substrates, and therefore initiate carbon remineralization in four distinct oceanic provinces: the boreal polar (BPLR), the Arctic oceanic (ARCT), the North Atlantic drift (NADR), and the North Atlantic subtropical (NAST) provinces. Since we expected the large-particle fraction to include phytoplankton cells, we measured the hydrolysis of polysaccharide substrates (laminarin, fucoidan, xylan, and chondroitin sulfate) expected to be associated with phytoplankton. Hydrolysis rates and patterns clustered into two groups, the BPLR/ARCT and the NADR/NAST. All four substrates were hydrolyzed by the BPLR/ARCT communities; hydrolysis rates of individual substrate varied by factors of ca. 1-4. In contrast, chondroitin was not hydrolyzed in the NADR/NAST, and hydrolytic activity was dominated by laminarinase. Fluorescence in situ hybridization of the large-particle fraction post-incubation showed a substantial contribution (15-26\%) of CF319a-positive cells (Bacteroidetes) to total DAPIstainable cells. Concurrent studies of microbial community composition and of fosmids from these same stations also demonstrated similarities between BPLR and ARCT stations, which were distinct from the NADR/NAST stations. Together, these data support a picture of compositionally as well as functionally distinct communities across these oceanic provinces.

Keywords: extracellular enzymes, biogeography, particles-associated bacteria, hydrolysis, carbon cycling

\section{INTRODUCTION}

Heterotrophic microbial communities collectively process a large fraction of the organic matter biosynthesized in the ocean (Azam, 1998), remineralizing, repackaging, and respiring a variety of substrates, and thus playing a central role in the marine carbon cycle. These communities have been shown recently to exhibit distinct biogeographic patterns in the ocean, with community composition differing by location, season, water mass, and depth (e.g., Kan et al., 2006; Agogue et al., 2011; Gilbert et al., 2012; Hanson et al., 2012). The consequences of these compositional differences for microbial community function are only beginning to be explored, however. The distribution of functional genes among communities at different locations, depths, and times in the ocean demonstrates the potential for distinct functionalities among these communities (DeLong et al., 2006; Teeling et al., 2012), but the conditions under which and extent to which potential differences in function might be expressed are still largely unknown. Although transcriptomic investigations have yielded insight into broad categories of genes that are active in marine microbial communities
(Poretsky et al., 2009; Shi et al., 2011), this approach has major limitations with respect to carbon cycling, due to the wide range of potential substrates in ocean waters and our very limited abilities to identify specific functional genes related to cycling of these substrates (e.g., Rebuffet et al., 2011).

Direct measurements of carbon processing by microbial communities demonstrate their abilities to take up specific low molecular weight substrates labeled with ${ }^{14} \mathrm{C}$ or ${ }^{3} \mathrm{H}$ (e.g., Rich et al., 1997; Vila-Costa et al., 2007; Alonso-Saez et al., 2008), but these studies yield only indirect information about the rate at which most natural marine organic matter is remineralized, since most marine organic matter is initially biosynthesized as macromolecules such as polysaccharides, proteins, and lipid complexes. Although marine macromolecules are present in much higher concentrations than low molecular weight organic matter, microbial access to these substrates requires hydrolysis by extracellular enzymes to produce substrates that can be transported across cell membranes for further processing (Arnosti, 2011). The activities of these enzymes thus initiate carbon cycling by heterotrophic 
microbial communities, and determine the types of organic matter that can serve as substrates.

Efforts to measure activities of microbial extracellular enzymes also - paradoxically - usually rely on a small number of low molecular weight substrate proxies. These commercially available proxies consist of a monomer such as glucose or leucine linked to a fluorophore whose fluorescence increases greatly upon hydrolysis of the monomer-fluorophore bond (Hoppe, 1983). This experimental approach has been used to compare potential hydrolysis rates at a wide range of depths and locations in the water column (e.g., Huston and Deming, 2002; Baltar et al., 2009; Piontek et al., 2011), and results have frequently been extrapolated to the degradation of carbohydrates and proteins in general (Christian and Karl, 1995; Fukuda et al., 2000). These substrate proxies, however, do not adequately mimic the three-dimensional structure of organic macromolecules in solution, so the relationship between hydrolysis rates measured with these proxies and the hydrolysis rates of their putative macromolecular counterparts are highly uncertain (Warren, 1996).

In order to measure the activities of enzymes responsible for hydrolysis of high molecular weight organic matter, alternative methods have been developed. These methods are intended also to detect the activities of endo-acting enzymes that cleave macromolecules mid-chain, an essential step in microbial degradation of macromolecular organic matter (Weiner et al., 2008; McBride et al., 2009). These approaches require synthesis of specific labeled substrates: fluorescently labeled polysaccharides and phytoplankton extracts (Arnosti, 1995, 2003; Arnosti et al., 2005b) or peptides (Pantoja et al., 1997, 2009; Pantoja and Lee, 1999), and chromatographic separation of the hydrolysis products, and thus requires considerably more work pre- and post-experiment. The additional effort is compensated for by the fact that these substrates can be used to investigate differences in hydrolysis rates and patterns for substrates with closely related structures, yielding new insight into the specific enzymatic capabilities of heterotrophic microbial communities in the water column and sediments. Using this approach, major functional differences among heterotrophic microbial communities at different depths and locations in the ocean have been identified (Arnosti et al., 2005a; Arnosti, 2008; Steen et al., 2012), showing that specific complements of enzyme activities are found not just for individual organisms, but among entire microbial communities. Moreover, these patterns of differences in enzyme activities have been shown to extend along large spatial gradients in the ocean (Arnosti et al., 2011), perhaps reflecting large-scale changes in microbial community composition along latitudinal gradients (Pommier et al., 2007; Fuhrman et al., 2008).

Given previous evidence of substantial differences in microbial communities in the North Atlantic (Schattenhofer et al., 2009), we tested whether organisms from distinct oceanic provinces within near-surface waters of the North Atlantic differed in their abilities to hydrolyze high molecular weight substrates. We focused in particular on a fraction of seawater enriched in large particles, since particle-associated heterotrophic communities are believed to be well-equipped to metabolize high molecular weight substrates, with enzymes that are sufficiently active so as to provide hydrolysate to the surrounding water column community as well as to the attached community (Smith et al., 1992; Simon et al., 2002; Grossart, 2010). At the conclusion of our incubation experiments, we carried out fluorescence in situ hybridization (FISH) staining to compare communities from the same station that had been incubated with different substrates, as well as communities obtained from different locations that were incubated with the same substrate. Concurrently conducted investigations of microbial community composition (Gomez-Pereira et al., 2010; Schattenhofer et al., 2011) and Bacteroidetes-associated fosmids (Gomez-Pereira et al., 2012) from the same locations provided us with the opportunity to examine the link between microbial community composition and function, and thus provided a larger context within which to interpret our measurements of microbial community activity. Together, these data provide new insight into the functional capabilities as well as the composition of microbial communities in distinct oceanic provinces of near-surface waters of the North Atlantic.

\section{MATERIALS AND METHODS SAMPLE COLLECTION AND WATER MASS IDENTIFICATION}

Water was collected at a depth of $20 \mathrm{~m}$ using Niskin bottles mounted on a rosette equipped with a CTD at four stations (S3, S6, S12, and S19) during the VISION cruise of the R/V Maria S. Merian (September/October 2006). The stations represented distinct oceanic provinces on a N-S gradient along the $30^{\circ} \mathrm{W}$ meridian. As discussed in detail in Gomez-Pereira et al. (2010), water mass provinces were defined via satellite-derived parameters including Advanced Very High Resolution Radiometer (AVHRR), sea surface temperature and Sea-viewing Wide Field-of-view Sensor (SeaWiFS) water leaving radiance, according to Oliver and Irwin (2008). By these definitions, S3 was in the boreal polar (BPLR), S6 was within the Arctic oceanic (ARCT) province, S12 was within the North Atlantic drift (NADR), and S19 was within the North Atlantic subtropical (NAST) province (Gomez-Pereira et al., 2010).

\section{SAMPLE PREPARATION AND MEASUREMENT OF EXTRACELLULAR ENZYMATIC HYDROLYSIS}

At each station, ca. $100 \mathrm{l}$ of seawater (combined contents of five Niskin bottles) were passed through a stainless steel cartridge filter (Wolf Technik, Weil der Stadt, Germany), resulting in approximately 11 retentate with particles larger than $10 \mu \mathrm{m}$ (Table 1). The microbial community of the retentate is operationally defined as the large-particle-associated fraction; this fraction was used for incubation experiments. We note that this operationally defined fraction necessarily contained some bacteria present in the surrounding seawater, since the particles in the retentate were not removed from surrounding water. Microscopy of the retentate revealed that protists (diatoms, dinoflagellates, ciliates, and many others) and ample debris of unknown origin were collected. Since large-particle-associated bacteria concentrated from the euphotic zone may preferentially be associated with phytoplankton cells, which are typically carbohydrate-rich (Parsons etal., 1961), we focused on measuring the potential of the bacteria retained within this fraction to hydrolyze high molecular weight substrates that would likely be associated 
Table 1 | Station location, sample volume, and physical and chemical characteristics of the water column at 20 m depth.

\begin{tabular}{|c|c|c|c|c|c|c|c|c|c|c|c|c|}
\hline Station & Position & $\begin{array}{l}\text { In situ } \\
\text { temper- } \\
\text { ature }\left({ }^{\circ} \mathrm{C}\right)\end{array}$ & $\begin{array}{l}\text { Salinity } \\
\text { (PSU)* }\end{array}$ & $\begin{array}{l}\text { Water } \\
\text { mass }\end{array}$ & \multicolumn{2}{|c|}{$\begin{array}{c}10 \mu \mathrm{m} \text { filter } \\
\text { concentration }\end{array}$} & $\begin{array}{l}\text { Concentration } \\
\text { factor }\end{array}$ & $\begin{array}{l}\mathrm{PO}_{4}{ }^{3-} \\
(\mu \mathrm{M})^{*}\end{array}$ & $\begin{array}{l}\mathrm{NO}_{3}{ }^{-} \\
(\mu \mathrm{M})^{*}\end{array}$ & $\begin{array}{l}\mathrm{NO}_{2}^{-} \\
(\mu \mathrm{M})^{*}\end{array}$ & $\begin{array}{l}\mathrm{NH}_{4}{ }^{+} \\
(\mu \mathrm{M})^{*}\end{array}$ & $\begin{array}{l}\text { Chl a } \\
\left(\mu \mathrm{gl}^{-1}\right)^{*}\end{array}$ \\
\hline S3 & $65^{\circ} 52.6^{\prime} \mathrm{N}$ & 0.6 & 33.0 & BPLR & 100 & 730 & 137 & 0.408 & 2.895 & 0.133 & 0.29 & 1.0 \\
\hline \multirow[t]{2}{*}{ S6 } & $59^{\circ} 20.9^{\prime} \mathrm{N}$ & 10.9 & 35.0 & ARCT & 96 & 850 & 113 & 0.432 & 5.437 & 0.21 & 0.584 & 1.7 \\
\hline & $29^{\circ} 59.9^{\prime} \mathrm{W}$ & & & & & & & & & & & \\
\hline \multirow[t]{2}{*}{ S12 } & $46^{\circ} 44.5^{\prime} \mathrm{N}$ & 18.3 & 35.9 & NADR & 93 & 750 & 124 & 0.062 & 0.315 & 0.051 & 0.707 & $\sim 0.2$ \\
\hline & $30^{\circ} 0.2^{\prime} \mathrm{W}$ & & & & & & & & & & & \\
\hline S19 & $34^{\circ} 24.8^{\prime} \mathrm{N}$ & 24.1 & 36.6 & NAST & 95 & 500 & 186 & 0.011 & 0.022 & 0.015 & 0.169 & $\sim 0.1$ \\
\hline
\end{tabular}

*Data from Gomez-Pereira et al. (2010).

with phytoplankton. Such substrates would include carbohydrates exudates, carbohydrate-containing cellular components, and phytoplankton-derived transparent exopolymeric particles (TEP; Painter, 1983; Passow et al., 1994; Myklestad, 1995). Four different fluorescently labeled polysaccharides (laminarin, xylan, fucoidan, and chondroitin sulfate) were therefore used to measure the activity of extracellular enzymes, after the method of Arnosti (1995, 2003). The polysaccharides were purchased from Sigma or Fluka, labeled with fluoresceinamine (Sigma; Isomer II), and characterized as described in Arnosti (2003). Laminarin $(\beta(1,3)$ glucose), xylan $(\beta(1,4)$ xylose), and fucoidan (sulfated fucose) are components of marine algae and phytoplankton (Parsons et al., 1961; Painter, 1983); fucoidan additionally has a chemical composition consistent with TEP (Zhou et al., 1998). Chondroitin sulfate is a marine-derived polysaccharide (a sulfated polymer of galactosamine and glucuronic acid $(\beta$-GlcA $(1,3)$-GalNAc $(1,4))$ that is rapidly hydrolyzed by heterotrophic microbial communities in seawater and sediments (Arnosti, 2008; Arnosti et al., 2009). Most of these polysaccharides are produced by marine phytoplankton and algae (Painter, 1983; Alderkamp et al., 2007). Moreover, activities of enzymes hydrolyzing all of these substrates have been measured in seawater and sediments (Arnosti et al., 2005a; Arnosti, 2008; Teske et al., 2011), and gene sequences corresponding to enzymes that would hydrolyze these substrate have also been identified in the genomes of recently sequenced marine bacteria (Glöckner et al., 2003; Bauer et al., 2006; Weiner et al., 2008).

At each station, four sets of substrate incubations were prepared: duplicate live incubations $(15 \mathrm{ml}$ each) and single killed control incubations ( $10 \mathrm{ml}$ seawater $+3.5 \mathrm{ml}$ formalin) for each substrate. Each substrate was added at a final concentration of 3.5 $\mu \mathrm{M}$ monomer-equivalent to the incubations. Incubations from $\mathrm{S} 3$ and $\mathrm{S} 6$ were incubated at $4^{\circ} \mathrm{C}$ in the dark in a temperaturecontrolled room; incubations from S12 and S19 were initially incubated at $18-23^{\circ} \mathrm{C}$ (in flowing seawater in the lab) and then were incubated at $20^{\circ} \mathrm{C}$ (temperature-controlled room) in the dark. Subsamples (ca. $2.5 \mathrm{ml}$ ) were removed from each incubation at 0,5 , and 15 days, filtered through a sterile $0.2-\mu \mathrm{m}$ pore-size filter, the first $1 \mathrm{ml}$ of filtrate was discarded, and the remaining $1.5 \mathrm{ml}$ of the filtrate was stored frozen until analysis. In brief, substrate hydrolysis was determined from the changes in polysaccharide molecular weight with time, as measured using gel permeation chromatography and fluorescence detection, described in detail in Arnosti (2003). Gel columns consisted of a $20 \mathrm{~cm} \times 1 \mathrm{~cm}$ column of Sephadex G-50 gel, connected in series to a $18.5 \mathrm{~cm} \times 1 \mathrm{~cm}$ column of Sephadex G-75 gel. Mobile phase (phosphate buffer, $\mathrm{pH}$

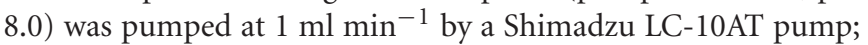
the column outflow passed through a Hitachi L-7480 fluorescence detector, set to excitation and emission wavelengths of 490 and $530 \mathrm{~nm}$, respectively. Hydrolysis rates were calculated from differences in substrate molecular weight at the different time points, as described in detail in Arnosti (2003).

\section{FLUORESCENCE IN SITU HYBRIDIZATION AND CELL COUNTS}

At the end of the 15-day incubation, the remaining incubation water $(\mathrm{ca} .7 .5 \mathrm{ml}$ ) from one of the two live replicates was fixed with particle-free formaldehyde, filtered through polycarbonate $0.2-\mu \mathrm{m}$ pore-sized filters, and the filters were stored frozen $\left(-20^{\circ} \mathrm{C}\right)$ until analysis. In situ identification with the standard catalyzed reporter deposition (CARD) FISH protocol (Pernthaler et al., 2002) and cell counting relative to total cell counts (DAPI) was carried out using the general bacterial probe mix EUB338 IIII (Daims et al., 1999) as well as the group-specific probes CF319a (Manz et al., 1996) and PLA46 (Neef et al., 1998; for a recent update of probe specificity see Amann and Fuchs, 2008) targeting Bacteroidetes and Planctomycetales, respectively. For two samples, insufficient volume was obtained to make accurate FISH counts, so relative abundances were estimated.

\section{RESULTS ENZYMATIC HYDROLYSIS RATES AND PATTERNS}

The four stations sampled represent different North Atlantic provinces, as characterized by distinctive temperature and salinity signatures, as well as nutrient and chlorophyll concentrations 
(Table 1; see Gomez-Pereira et al., 2010 for further details). They also showed distinct patterns and rates of extracellular enzymatic activities. Figure 1 shows the maximum hydrolysis rate of each substrate at each station, which was measured after either 5 or 15 days incubation. Maximal rates were observed after 5 days of incubation for fucoidan from all stations, for laminarin from all stations except S6, and for xylan from S12 and S19. The maximal hydrolysis rates of xylan from S3 and S6, of laminarin from S6, and of chondroitin at S3 and S6 were observed after 15 days of incubation. Data from both time points ( 5 and 15 days) are plotted in Figure 1 because in cases where substrates are hydrolyzed rapidly (e.g., maximum values at 5 days), later time points (e.g., 15 days) typically show a lower calculated hydrolysis rate, reflecting the fact that hydrolysis was nearly complete at the earlier time.

The differences in timescales over which hydrolysis rates reach a maximum rate reflect the activity and distribution of extracellular enzymes within a given community. Since hydrolysis of fluorescently labeled polysaccharides is detected as a change in the molecular weight distribution of the entire pool of added substrate (see Arnosti, 1995, 2003 for more details), extended incubations (timescales of days) are typically required to measure activity in pelagic samples. An enzyme activity that is low or is uncommon among a community is first observable after a more extended period of incubation, while enzyme activities that are intrinsically rapid or are widespread among a given community may be observed at an earlier time point. Since these timescales of measurement (days) allow sufficient time for community growth as well as enzyme expression, enzyme activities measured using this technique represent the potential of a community to react to substrate input - e.g., by induction of genes and/or by growth of a numerically small or slow-growing members of the community - rather than reflecting only the activity of enzymes already present at the time substrate is added to the sample. We note also that in this incubation, the time points were quite widely spaced; maximum hydrolysis rates might have been

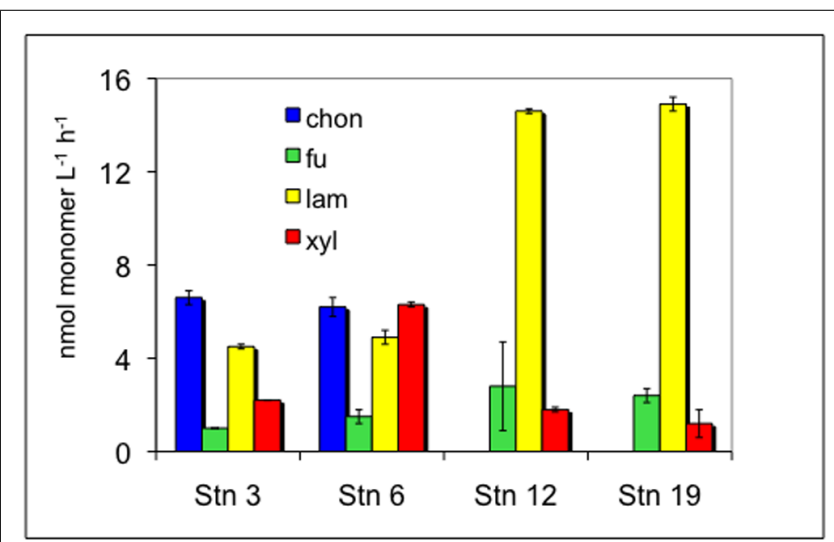

FIGURE 1 | Enzymatic hydrolysis rates of four polysaccharides in $\mathbf{1 0} \mu \mathbf{m}$ retentate from each station. Chon, chondroitin sulfate; fu, fucoidan; lam, laminarin; xyl, xylan. Bars show standard deviation of two replicate incubations. Hydrolysis rates are maximum rates that were measured after 5 days incubation for all substrates except chondroitin, laminarin at S6, and xylan at S3 and S6, which were from 15 days incubation (see text). reached prior to 5 or 15 days, so the rates reported here could be underestimated. We also note that these measurements necessarily represent the potential of the microbial community present in the sample at the time of collection. Samples collected at different seasons could show different patterns, depending on larger-scale factors that could drive seasonal variation in microbial community composition.

\section{HYDROLYSIS PATTERNS BY STATION}

As a pair, S3 and S6 resembled each other in hydrolysis rates and patterns. At these stations, all four substrates were hydrolyzed by the large-particle-associated microbial fraction. Hydrolysis rates of chondroitin were quite high; the hydrolysis rates of the other substrates were for the most part within a factor of ca. 1-4 of the chondroitin hydrolysis rate. At S12 and S19, in contrast, hydrolytic activity was highest for laminarin, which was very rapidly hydrolyzed (14.6 and $14.9 \mathrm{nmol} \mathrm{l}^{-1} \mathrm{~h}^{-1}$, respectively). Hydrolysis rates of fucoidan and xylan at S12 and S19 were 5-20 times lower than that of laminarin, and there was no indication of chondroitin hydrolysis in the large-particle-associated fraction from these stations.

\section{MICROBIAL COMMUNITY COMPOSITION}

The composition of the microbial communities at the conclusion of the incubation was investigated using CARD-FISH. The general bacterial probe mixture EUB338 I-III hybridized to 75-99\% of all DAPI-stained cells. Of these bacteria, a substantial proportion was assigned to Bacteroidetes with probe CF319a: on average, 26, 22, 15 , and $17 \%$ for S3, S6, S12, and S19, respectively (Table 2). Counts with the probe PLA46 specific for Planctomycetes were low or below the detection limit at all stations (data not shown), serving also as a negative control for unspecific staining and autofluorescence. For any given station, there was no consistent relationship between hydrolysis rate of a specific substrate and fraction of cells detected by CF319a.

\section{DISCUSSION}

The enzymatic complement of heterotrophic bacteria is variable even among closely related organisms (Gao et al., 2003;

Table 2 | CF319a hybridized cells, as \% DAPI-stained cells, after 15-day incubation with substrate.

\begin{tabular}{lllll}
\hline Substrate & \multicolumn{4}{c}{ Station } \\
\cline { 2 - 5 } & S3 & S6 & S12 & S19 \\
\hline Lam & 23.6 & 13.5 & 19.4 & $10-20^{*}$ \\
Xyl & 28.3 & 22.7 & 13.9 & $5-10^{*}$ \\
Fu & 17.3 & 13.9 & 10.2 & 19.3 \\
Chon & 34.3 & 36.7 & 15.8 & 14.7 \\
Average & 25.9 & 21.7 & 14.8 & 17.0 \\
Bulk water** & 19.7 & 17.5 & 30.6 & 5.4 \\
\hline
\end{tabular}

Lam, laminarin; xyl, xylan; fu, fucoidan; chon, chondroitin sulfate.

*Estimated abundance: volume too low to count precisely (see text). These values not included in the average.

* Bulk water: CF319a-stained cells (as \% of DAPI-stained cells) from a depth of $20 \mathrm{~m}$ at each station; data from Gomez-Pereira et al. (2010). 
Gomez-Pereira et al., 2012), so the nature and type of substrate that can be accessed by a given organism is quite specific, as has been demonstrated by microbiological and genomic investigations of a variety of prokaryotes (e.g., Martinez et al., 1996; Ensor et al., 1999; Glöckner et al., 2003; Bauer et al., 2006; Weiner et al., 2008). Some bacteria are able to use low molecular weight hydrolysis products although they cannot effectively hydrolyze the initial substrates (Cotta, 1992), demonstrating the necessity for close interactions among specific bacteria within a community. The extent to which substrate preference patterns extend from specific organisms to entire microbial communities, however, is only beginning to be explored in marine environments. Previous studies of polysaccharide hydrolysis by pelagic microbial communities demonstrate site-specific differences in extracellular enzymatic hydrolysis rates and patterns (Arnosti et al., 2005a; Steen et al., 2008) as well as large-scale latitudinal gradients in the spectrum of polysaccharide hydrolases activities in surface ocean waters (Arnosti et al., 2011). The observation that enzymatic hydrolysis patterns measured here clustered into two groups, consisting of the northern BPLR/ARCT stations S3 and S6, and the more temperate NADR/NAST stations S12 and S19 (Figure 1) suggests that there are biogeographic patterns in enzymatic capabilities also among the large-particle-associated fraction of microbial communities.

These functionally distinct communities also differed in composition, as shown by FISH staining of whole water (unsorted) as well as flow cytometry-sorted samples collected concurrently with the present study. Although members of the SAR11 were the single largest constituents of the unsorted population, contributing $25-32 \%$ of the total stained cells at a depth of $20 \mathrm{~m}$ at all four stations, the contribution of other prokaryotic cells was quite variable by station (Schattenhofer et al., 2011; Figure 2). CF319astainable cells (Bacteroidetes) contributed a large fraction of the identifiable cells, Syn405 (Synechococcus) counts were significant only in S3 and S6, while Pro405 (Prochlorococcus) counts were significant only at S12 and S19 (Figure 2; Schattenhofer et al., 2011). The fundamental factors shaping these differences in microbial community composition remain to be determined (Hanson et al., 2012); as noted by Schattenhofer et al. (2011), specific groups of bacterioplankton were statistically correlated with physical, chemical, and biological parameters, in agreement with investigations of other microbial communities at other locations (Kan et al., 2006; Gilbert et al., 2012). In any case, the general trend of a north to south decrease in nutrient and chlorophyll $a$ concentrations as well as picoeukaryotic abundance and prokaryotic counts at S3, S6, S12, and S19 tracks the changes in prokaryotic community composition and extracellular enzyme activities measured at the four stations (Table 1; Figure 2).

Compositional distinctions among the microbial communities at these four stations were supported also by more detailed analysis of bacteroidetal communities, carried out on the filtrate that had passed through the $10 \mu \mathrm{m}$ cartridge. A focus on members of the class Flavobacteria of the phylum Bacteroidetes is especially relevant due to their proven abilities to degrade organic macromolecules in marine waters (Kirchman, 2002; Bauer et al., 2006), as well as their abundance at these stations and in our incubations (Table 2). Analysis of 16S rRNA gene clone libraries and direct cell counts via CARD-FISH demonstrated that the flavobacterial composition of S3 and S6 had considerable overlap, sharing 25$40 \%$ of flavobacterial phylotypes, while S3 and S18 were mostly unrelated, sharing just $2-5 \%$ of flavobacterial phylotypes (GomezPereira etal., 2010). Flavobacteria are a major target of FISH probe CF319a, which comprised a substantial proportion (5-31\%) of cells in bulk seawater (Gomez-Pereira et al., 2010) as well as $15-26 \%$ of the post-incubation large-particle-associated fraction from these stations (Table 2). Since the complement of glycosyl hydrolase genes in fully sequenced members of the Bacteroidetes differs substantially (Gomez-Pereira et al., 2012), these differences in flavobacterial community composition indicate the potential for functional differences.

Evidence of biogeographic patterns in polysaccharide hydrolase activities (Figures $\mathbf{1}$ and 2) is also supported by the results of a metagenomic investigation based on analysis of Bacteroidetesassociated fosmids obtained from S3 and S18, the same samples Gomez-Pereira et al. (2010) used for clone libraries and CARDFISH staining. Fifteen glycosyl hydrolase-associated genes were identified in the fosmids, some of which included signal sequences that predicted enzyme export to the outer membrane (GomezPereira etal., 2012), where they could hydrolyze extracellular polysaccharides. At S3, genes corresponding to sulfatases (used to remove sulfate groups from polysaccharides) were also identified; most of these enzymes were likewise predicted to be exported from the cytoplasm (Gomez-Pereira et al., 2012), and thus to play a role in extracellular hydrolysis. Sulfatase genes were also identified at S18, in lower numbers than at S3. Overall, the relative content of glycosyl hydrolases and sulfatases at S3 was higher than at S18; differences in gene abundance were correlated with the abundance of the organisms from which the fosmid sequences were derived (Gomez-Pereira et al., 2012). The current study thus provides evidence of functional differences that are implied by the genomic and community population data from samples collected concurrently from these same stations (Gomez-Pereira et al., 2010, 2012; Schattenhofer et al., 2011).

Although differences in patterns of enzymatic hydrolysis (Figures 1 and 2) suggest fundamental differences in function of the large-particle-associated fraction of the community, information about relative gene abundance at different stations (Gomez-Pereira et al., 2012) cannot be linked directly to specific rates of hydrolysis. The extent and conditions under which a given gene is expressed in the environment are unknown; moreover, the kinetic characteristics of the enzymes themselves as well as the quantity of enzymes produced contribute to observed hydrolysis rates. Furthermore, the hydrolysis rates measured in this study may be affected by the fraction of large particles retained by the $10 \mu \mathrm{m}$ cartridge filter, as well as by the extent of particle colonization by bacteria at each station. The DNA extractions of Gomez-Pereira et al. $(2010,2012)$ were carried out on the fraction of water that passed through the $10 \mu \mathrm{m}$ cartridge, i.e., on the filtrate, rather than the retentate, and thus specifically excluded the large-particle-associated fraction used to measure enzyme activities in the current study. The retentate fraction, however, was isolated within a background of retained seawater (i.e., particles were not isolated from their surrounding solution), and therefore also contained some cells that were present in the last fraction 


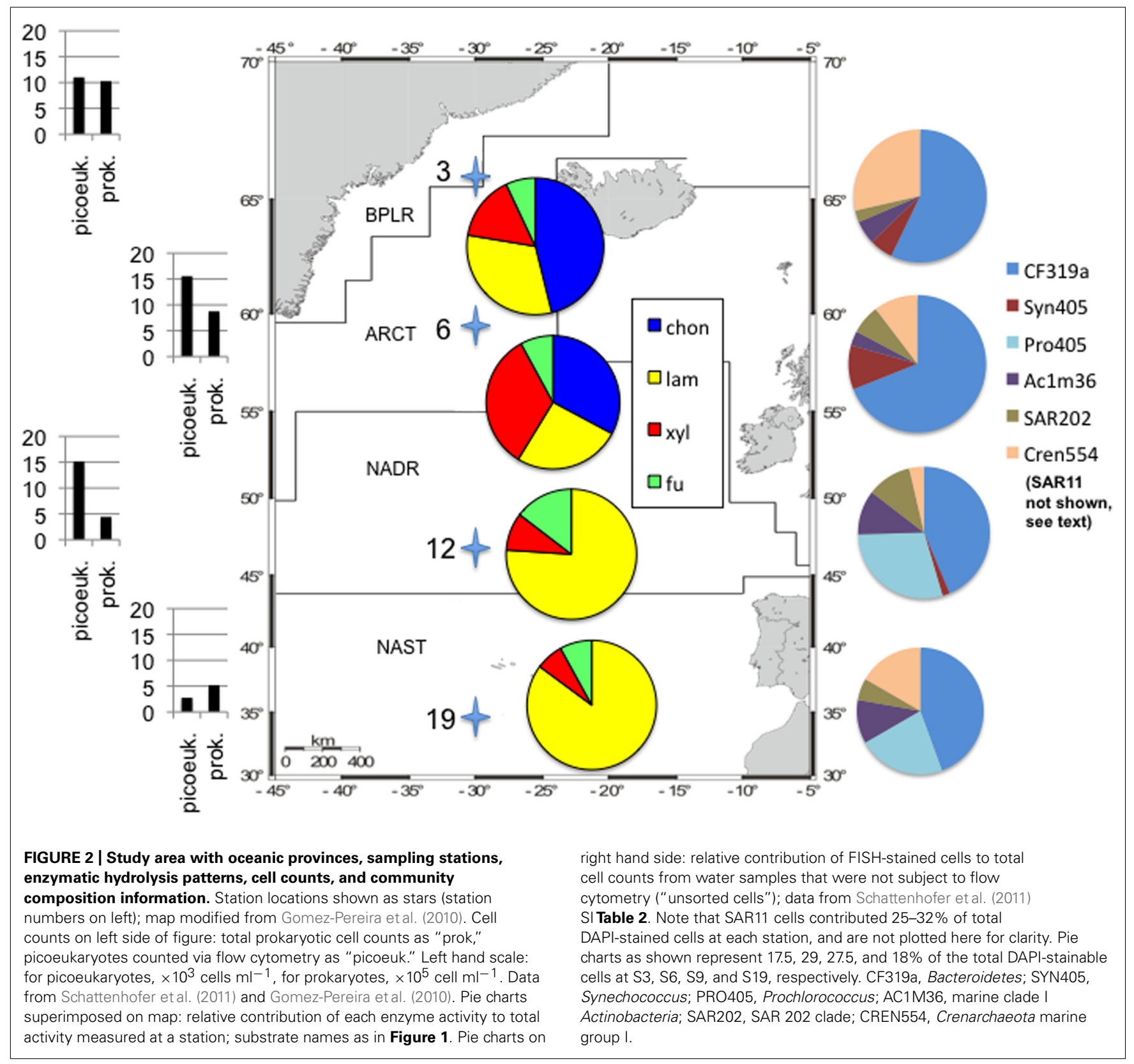

to pass into the cartridge filter. Substrate hydrolysis rates showed no systematic relationship with concentration factor (Table 1), also indicating that the differences observed among stations were not an outcome of sample manipulation. Furthermore, Schattenhofer etal. (2011) did not prefilter their samples, and the population they studied (Figure 2) would thus also include the fraction defined here as large-particle-associated bacteria. In any case, any differences between stations in bacterial cell numbers of the large-particle-associated fraction would be reflected primarily in differences in the rates of hydrolysis, and not in the patterns of substrates hydrolyzed. Different patterns of substrate hydrolysis point instead at functionally different communities.

The patterns evident at these stations additionally demonstrate that enzymatic hydrolysis rates in pelagic waters are not a simple function of environmental temperature. Although in situ as well as incubation temperatures at S12 and S19 were substantially warmer than at S3 and S6, only laminarin hydrolysis rates appear to track temperature. Hydrolysis rates of fucoidan, chondroitin, and xylan, in contrast, were comparable to or higher at the colder stations (S3/S6) than at the warmer stations (S12/S19). A correlation of laminarin hydrolysis with temperature, and little temperature correlation for other polysaccharides, is in fact a pattern consistent with enzyme activities in surface ocean waters on latitudinal gradients (Arnosti et al., 2011).

The lack of measurable chondroitin hydrolysis at S12 and S19 is particularly interesting in light of the observation that it is one of the activities frequently measured in surface ocean waters (Arnosti et al., 2011). At these stations, hydrolytic activity may be 
associated with the free living or small-particle-associated microbial fraction that would not have been retained by a $10-\mu \mathrm{m}$ filter. This activity may also simply be missing in this biogeographic province, since evidence to date suggests that enzymatic capabilities are non-uniformly distributed in the surface ocean (Arnosti et al., 2005a, 2011; Steen et al., 2008), and polysaccharide hydrolase gene distribution varied among these stations (Gomez-Pereira et al., 2012). Conversely, fucoidan hydrolysis at all four stations is also notable, since it is an activity that is relatively infrequently measured in surface ocean waters (Arnosti et al., 2011), and perhaps is primarily associated with large-particle-associated bacteria. Both chondroitin and fucoidan are sulfated polysaccharides, and their rates and extent of utilization may also be related to the activities of sulfatase enzymes whose genes were identified in the fosmids from these stations (Gomez-Pereira et al., 2012). The pattern of more rapid chondroitin hydrolysis upon extended incubation (i.e., 15 days) is consistent with previous observations of chondroitin hydrolysis in marine waters and sediments, as well as experiments indicating that chondroitin hydrolysis is induced in marine bacteria (Arnosti, 2004).

Our CARD-FISH identifications focused on the potential enrichment of two bacterial phyla that had been linked to degradation of (sulfated) polysaccharide, Planctomycetales (Glöckner et al., 2003; Woebken et al., 2007) and Bacteroidetes (Kirchman, 2002; Bauer et al., 2006). Whereas we could not detect significant numbers of Planctomycetales with probe PLA46, there was consistently a strong contribution of CF319a-positive bacteroidetal cells in the large-particle-associated fraction post-incubation (Table 2). This result is consistent with the observation that members of the phylum Bacteroidetes - and in particular those of the class Flavobacteria - are frequently associated with phytoplankton blooms (Gomez-Pereira et al., 2012; Teeling et al., 2012). FISH staining showed somewhat higher average counts of CF319astainable cells at S3/S6 compared to S12/S19, a result likely due

\section{REFERENCES}

Agogue, H., Lamy, D., Neal, P. R., Sogin, M. L., and Herndl, G. J. (2011). Water mass specificity of bacterial communities in the North Atlantic revealed by massively parallel sequencing. Mol. Ecol. 20, 258-274.

Alderkamp, A.-C., Van Rijssel, M., and Bolhuis, H. (2007). Characterization of marine bacteria and the activity of their enzyme systems involved in degradation of the algal storage glucan laminarin. FEMS Microbiol. Ecol. 59, 108-117.

Allison, S. D., Chao, Y., Farrara, J. D., Hatosy, S., and Martiny, A. C. (2012). Fine-scale temporal variation in marine extracellular enzymes of coastal southern California. Front. Microbiol. 3:301. doi: $10.3389 /$ fmicb. 2012.00301

Alonso-Saez, L., Sanchez, O., Gasol, J. M., Balague, V., and Pedros-Alio, C. (2008). Winter-to-summer changes in the composition and single-cell activity of near-surface Arctic prokaryotes. Environ. Microbiol. 10, 2444-2454.

Amann, R., and Fuchs, B. (2008). Single-cell identification in microbial communities by improved fluorescence in situ hybridization techniques. Nat. Rev. Microbiol. 6, 339-348. depth- and site-related differences marine sediments. Geochim. Cosmochim. Acta 59, 4247-4257.

Arnosti, C. (2003). Fluorescent derivatization of polysaccharides and carbohydrate-containing biopolymers for measurement of enzyme activities in complex media. J. Chromatogr. B Analyt. Technol. Biomed. Life Sci. 793, 181-191.

Arnosti, C. (2004). Speed bumps and barricades in the carbon cycle: substrate structural effects on carbon cycling. Mar. Chem. 92, 263-273.

Arnosti, C. (2008). Functional differences between Arctic sedimentary
Arnosti, C. (1995). Measurement of in polysaccharide hydrolysis rates in

to initial differences in phytoplankton (Figure 2; Gomez-Pereira et al., 2010) as well as to microbial growth in response to substrate addition. Specific differences in functional potential of these organisms, however, became evident only through direct measurement of extracellular enzyme activities, using an experimental approach that provides information about structural specificities of these enzymes. This investigation is the first to specifically focus on the hydrolytic capabilities of large-particle-associated bacteria to hydrolyze these substrates; it is also the first investigation to combine FISH staining directly with these measurements. These communities evidently exhibit distinct patterns in enzyme activities, as has been observed for unfiltered surface and subsurface waters (Arnosti et al., 2005a, 2011; Steen et al., 2008, 2012). The extent to which patterns of enzyme activities may differ for large particles vs. whole water should be a focal point of further work, as should the extent to which such patterns may change through annual cycles of phytoplankton and bacterial succession (Allison et al., 2012; Gilbert et al., 2012). Such investigations will help us define more precisely at a functional level the contributions of specific microbial communities to carbon processing in the ocean.

\section{ACKNOWLEDGMENTS}

We thank the captain, crew, and scientific party of R/V Maria S. Merian for a successful cruise, and Antje Wichels and Gunnar Gerdts help in sample collection. We are particularly grateful to Jörg Wulf and Birgit Rattunde for their meticulous efforts to obtain FISH data from minimal sample volume. This project was supported by the Max Planck Society. Additional support to Carol Arnosti was provided by the U.S. National Science Foundation (OCE-0323975 and OCE-0848703), as well as by the Alfred Wegener Institute for Polar and Marine Research, and the HanseWissenschaftskolleg (Delmenhorst). Additional support to Uta Passow was provided by the U.S. National Science Foundation (OCE-0926711 and OCE-1041038).

and seawater microbial communities: contrasts in microbial hydrolysis of complex substrates. FEMS Microbiol. Ecol. 66, 343-351.

Arnosti, C. (2011). Microbial extracellular enzymes and the marine carbon cycle. Annu. Rev. Mar. Sci. 3 401-425.

Arnosti, C., Durkin, S., and Jeffrey, W. H. (2005a). Patterns of extracellular enzyme activities among pelagic marine microbial communities: implications for cycling of dissolved organic carbon. Aquat. Microb. Ecol. 38, 135-145.

Arnosti, C., Finke, N., Larsen, O., and Ghobrial, S. (2005b). Anoxic carbon degradation in Arctic sediments: microbial transformations of complex substrates. Geochim. Cosmochim. Acta 69, 2309-2320.

Arnosti, C., Steen, A. D., Ziervogel, K., Ghobrial, S., and Jeffrey, W. H. (2011). Latitudinal gradients in degradation of marine dissolved organic carbon. PLOS ONE 6:e28900. doi: 10.1371/journal.pone. 0028900

Arnosti, C., Ziervogel, K., Ocampo, L., and Ghobrial, S. (2009). Enzyme activities in shallow permeable sediments and the water column from the northeastern Gulf of Mexico. Estuar. Coast. Shelf Sci. 84, 202-208.

Azam, F. (1998). Microbial control of oceanic carbon flux: the plot thickens. Science 280, 694-696.

Baltar, F., Aristegui, J., Sintes, E., Van Aken, H. M., Gasol, J. M., and Herndl, G. J. (2009). Prokaryotic extracellular enzymatic activity in relation to biomass production and respiration in the meso- and bathypelagic waters of the (sub)tropical Atlantic. Environ. Microbiol. 11, 1998-2014.

Bauer, M., Kube, M., Telling, H., Richter, M., Lombardot, T., Allers, E., et al. (2006). Whole genome analysis of the marine Bacteroidetes 'Gramella forsetii' reveals adaptations to degradation of polymeric organic 
matter. Environ. Microbiol. 8, 22012213.

Christian, J. R., and Karl, D. M. (1995). Bacterial ectoenzymes in marine waters: activity ratios and temperature responses in three oceanographic provinces. Limnol. Oceanogr. 40, 1042-1049.

Cotta, M. A. (1992). Interaction of ruminal bacteria in the production and utilization of maltooligosaccharides from starch. Appl. Environ. Microbiol. 58, 48-54.

Daims, H., Brühl, A., Amann, R., Schleifer, K.-H., and Wagner, M. (1999). The domain-specific probe EUB338 is insufficient for the detection of all bacteria: development and evaluation of a more comprehensive probe set. Syst. Appl. Microbiol. 22, 434-444.

DeLong, E. F., Preston, C. M., Mincer, T., Rich, V., Hallam, S. J., Frigaard, N.-U., et al. (2006). Community genomics among stratified microbial assemblages in the ocean's interior. Science 311, 496-503.

Ensor, L. A., Stosz, S. K., and Weiner, R. M. (1999). Expression of multiple complex polysaccharidedegrading enzyme systems by marine bacterium strain 2-40. J. Ind. Microbiol. Biotechnol. 23, 123-126.

Fuhrman, J. A., Steele, J. A., Hewson, I., Schwalbach, M. S., Brown, M. V., Green, J. L., et al. (2008). A latitudinal diversity gradient in planktonic marine bacteria. Proc. Natl. Acad. Sci. U.S.A. 105, 7774-7778.

Fukuda, R., Sohrin, Y., Saotome, N., Fukuda, H., Nagata, T., and Koike, I. (2000). East-west gradient in ectoenzyme activities in the subarctic Pacific: possible regulation by zinc. Limnol. Oceanogr. 45, 930-939.

Gao, J., Bauer, M. W., Shockley, K. R., Pysz, M. A., and Kelly, R. M. (2003). Growth of hyperthermophilic archaeon Pyrococcus furiosus on chitin involves two family 18 chitinases. Appl. Environ. Microbiol. 69, 3119-3128.

Gilbert, J. A., Steele, J. A., Caporaso, J. G., Steinbruck, L., Reeder, J., Temperton, B., et al. (2012). Defining seasonal marine microbial community dynamics. ISME J. 6, 298-308.

Glöckner, F. O., Kube, M., Bauer, M., Teeling, H., Lombardot, T., Ludwig, W., et al. (2003). Complete genome sequence of the marine planctomycete Pirellula sp. strain 1. Proc. Natl. Acad. Sci. U.S.A. 100, 82988303.

Gomez-Pereira, P. R., Fuchs, B. M., Alonso, C., Oliver, M. J., Van Beusekom, J. E. E., and Amann, R. (2010). Distinct flavobacterial communities in contrasting water masses of the North Atlantic Ocean. ISME J. 4, 472-487.

Gomez-Pereira, P. R., Schuler, M., Fuchs, B. M., Bennke, C. M., Teeling, H., Waldmann, J., et al. (2012). Genomic content of uncultured Bacteroidetes from contrasting oceanic provinces in the North Atlantic Ocean. Environ. Microbiol. $14,52-66$.

Grossart, H.-P. (2010). Ecological consequences of bacterioplankton lifestyles: changes in concepts are needed. Environ. Microbiol. Rep. 2, 706-714.

Hanson, C. A., Fuhrman, J. A., HornerDevine, M. C., and Martiny, J. B. H. (2012). Beyond biogeographic patterns: processes shaping the microbial landscape. Nat. Rev. Microbiol. 10, 497-506.

Hoppe, H.-G. (1983). Significance of exoenzymatic activities in the ecology of brackish water: measurements by means of methylumbelliferylsubstrates. Mar. Ecol. Prog. Ser. 11, 299-308.

Huston, A. L., and Deming, J. W. (2002). Relationships between microbial extracellular enzymatic activity and suspended and sinking particulate organic matter: seasonal transformations in the North Water. Deep Sea Res. 2 Top. Stud. Oceanogr. 49, 5211-5225.

Kan, J., Crump, B. C., Wang, K. and Chen, F. (2006). Bacterioplankton community in Chesapeake Bay: predictable or random assemblages. Limnol. Oceanogr. 51, 2157-2169.

Kirchman, D. L. (2002). The ecology of the Cytophaga-Flavobacteria in aquatic environments. FEMS Microbiol. Ecol. 39, 91-100.

Manz, W., Amann, R., Ludwig, W. Vancanneyt, M., and Schleifer, K.-H. (1996). Application of a suite of 16S rRNA-specific oligonucleotide probes designed to investigate bacteria of the phylum CytophagaFlavobacter-bacteroides in the natural environment. Microbiology. 142, 1097-1106

Martinez, J., Smith, D. C., Steward, G. F., and Azam, F. (1996). Variability in ectohydrolytic enzyme activities of pelagic marine bacteria and its significance for substrate processing in the sea. Aquat. Microb. Ecol. 10, 223-230. McBride, M. J., Xie, G., Martens, E. C. Lapidus, A., Henrissat, B., Rhodes, R. G., etal. (2009). Novel features of the polysaccharide-digesting gliding bacterium Flavobacterium johnsoniae as revealed by genome sequence analysis. Appl. Environ. Microbiol. 75, 6864-6875.
Myklestad, S. M. (1995). Release of extracellular products by phytoplankton with special emphasis on polysaccharides. Sci. Total Environ. 165, 155-164.

Neef, A., Amann, R., Schlesner, H., and Schleifer, K.-H. (1998) Monitoring a widespread bacterial group: in situ detection of Planctomycetes with 16S rRNA-targeted probes. Microbiology 144, 3257-3266.

Oliver, M. J., and Irwin, A. J. (2008). Objective global ocean biogeographic provinces. Geophys. Res. Lett. 35, L15601.

Painter, T. J. (1983). "Algal polysaccharides," in The Polysaccharides, ed. G. O. Aspinall (New York: Academic Press), 195-285.

Pantoja, S., and Lee, C. (1999). Peptide decomposition by extracellular hydrolysis in coastal seawater and salt marsh sediment. Mar. Chem. 63, 273-291.

Pantoja, S., Lee, C., and Marecek, J. F. (1997). Hydrolysis of peptides in seawater and sediments. Mar. Chem. 57, 25-40.

Pantoja, S., Rossel, P., Castro, R., Cuevas, L. A., Daneri, G., and Lee, C. (2009) Microbial degradation rates of small peptides and amino acids in the oxygen minimum zone of Chilean coastal waters. Deep Sea Res. Part II Top. Stud. Oceanogr. 56, 1055-1062.

Parsons, T. R., Stephens, K., and Strickland, J. D. H. (1961). On the chemical composition of eleven species of marine phytoplankton. J. Fish. Res. Bd. Canada 18, 1001-1016.

Passow, U., Alldredge, A. L., and Logan, B. E. (1994). The role of particulate carbohydrate exudates in the flocculation of diatom blooms. Deep Sea Res. Part I Oceanogr. Res. Pap. 41, 335-357.

Pernthaler, A., Pernthaler, J., and Amann, R. (2002). Fluorescence in situ hybridization and catalyzed reporter deposition for the identification of marine bacteria. Appl. Environ. Microbiol. 68, 3094-3101.

Piontek, J., Handel, N., Debodt, C., Harlay, J., Chou, L., and Engel, A. (2011). The utilization of polysaccharides by heterotrophic bacterioplankton in the Bay of Biscay (North Atlantic Ocean). J. Plankton Res. 33, 1719-1735.

Pommier, T., Canback, B., Riemann, L., Bostrom, K. H., Simu, K., Lundberg P., et al. (2007). Global patterns of diversity and community structure in marine bacterioplankton. Mol. Ecol. 16, 867-880.

Poretsky, R. S., Sun, S., Mou, X., and Moran, M. A. (2009). Transporter genes expressed by coastal bacterioplankton in response to dissolved organic carbon. Environ. Microbiol. 12, 616-627.

Rebuffet, E., Groisillier, A., Thompson, A., Jeudy, A., Barbeyron, T., Czjzek, M., et al. (2011). Discovery and structural characterization of a novel glycosidase family of marine origin. Environ. Microbiol. 13, 12531270.

Rich, J., Gosselin, M., Sherr, E., Sherr, B., and Kirchman, D. L. (1997). High bacterial production, uptake and concentrations of dissolved organic matter in the Central Arctic Ocean. Deep Sea Res. Res. Part II Top. Stud. Oceanogr. 44, 1645-1663.

Schattenhofer, M., Fuchs, B. M., Amann, R., Zubkov, M. V., Tarran, G. A., and Pernthaler, J. (2009). Latitudinal distribution of prokaryotic picoplankton populations in the Atlantic Ocean. Environ. Microbiol. 11, 2078-2093.

Schattenhofer, M., Wulf, J., Kostadinov, I., Glöckner, F. O., Zubkov, M. V., and Fuchs, B. M. (2011). Phylogenetic characterisation of picoplanktonic populations with high and low nucleic acid content in the North Atlantic Ocean. Syst. Appl. Microbiol. 34, 470-475.

Shi, Y., Tyson, G. W., Eppley, J. M., and Delong, E. F. (2011). Integrated metatranscriptomic and metagenomic analyses of stratified microbial assemblages in the open ocean. ISME J. 5, 999-1013.

Simon, M., Grossart, H.-P., Schweitzer, B., and Ploug, H. (2002). Microbial ecology of organic aggregates in aquatic ecosystems. Aquat. Microb. Ecol. 28, 175-211.

Smith, D. C., Simon, M., Alldredge, A. L., and Azam, F. (1992). Intense hydrolytic enzyme activity on marine aggregates and implications for rapid particle dissolution. Nature 359, 139-142.

Steen, A. D., Hamdan, L., and Arnosti, C. (2008). Dynamics of high molecular weight dissolved organic carbon in the Chesapeake Bay: insights from enzyme activities, carbohydrate concentrations, and microbial metabolism. Limnol. Oceanogr. 53, 936-947.

Steen, A. D., Ziervogel, K., Ghobrial, S., and Arnosti, C. (2012). Functional variation among polysaccharidehydrolyzing microbial communities in the Gulf of Mexico. Mar. Chem. 138, 13-20.

Teeling, H., Fuchs, B. M., Becher, D., Klockow, C., Gardebrecht, A., Bennke, C. M., etal. (2012). Substrate-controlled succession of marine bacterioplankton populations 
induced by a phytoplankton bloom. Science 336, 608-611.

Teske, A., Durbin, A., Ziervogel, K., Cox, C., and Arnosti, C. (2011). Microbial community composition and function in permanently cold seawater and sediments from an Arctic fjord of Svalbard. Appl. Environ. Microbiol. 77, 208-218.

Vila-Costa, M., Pinhassi, J., Alonso, C., Pernthaler, J., and Simo, R. (2007). An annual cycle of dimethylsulfoniopropionate-sulfur and leucine assimilating bacterioplankton in the coastal NW Mediterranean. Environ. Microbiol. 9, 2451-2463.

Warren, R. A. J. (1996). Microbial hydrolysis of polysaccharides.
Annu. Rev. Microbiol. 50, 183-212.

Weiner, R. M., Taylor Ii, L. E., Henrissat, B., Hauser, L., Land, M., Coutinho, P. M., etal. (2008). Complete genome sequence of the complex carbohydrate-degrading marine bacterium, Saccharophagus degradans Strain 2-40T. PLoS Genet. 5:e1000087. doi: 10.1371/journal. pgen. 1000087

Woebken, D., Teeling, H., Wecker, P., Dumitriu, A., Kostadinov, I., DeLong, E. F., et al. (2007). Fosmids of novel marine planctomycetes from the Namibian and Oregon coast upwelling systems and their cross-comparison with planctomycete genomes. ISME J. 1, 419-435
Zhou, J., Mopper, K., and Passow, U. (1998). The role of surface-active carbohydrates in the formation of transparent exopolymer particles by bubble adsorption of seawater. Limnol. Oceanogr. 43, 1860-1871.

Conflict of Interest Statement: The authors declare that the research was conducted in the absence of any commercial or financial relationships that could be construed as a potential conflict of interest.

Received: 29 July 2012; accepted: 27 November 2012; published online: 13 December 2012.
Citation: Arnosti C, Fuchs BM, Amann $R$ and Passow $U$ (2012) Contrasting extracellular enzyme activities of particle-associated bacteria from distinct provinces of the North Atlantic Ocean. Front. Microbio. 3:425. doi: 10.3389/ fmicb.2012.00425

This article was submitted to Frontiers in Aquatic Microbiology, a specialty of Frontiers in Microbiology.

Copyright $\odot 2012$ Arnosti, Fuchs, Amann and Passow. This is an open-access article distributed under the terms of the Creative Commons Attribution License, which permits use, distribution and reproduction in other forums, provided the original authors and source are credited and subject to any copyright notices concerning any third-party graphics etc. 